Article

\title{
Development of a 3D Underground Cadastral System with Indoor Mapping for As-Built BIM: The Case Study of Gangnam Subway Station in Korea
}

\author{
Sangmin Kim ${ }^{1}$, Jeonghyun Kim ${ }^{1}$, Jaehoon Jung ${ }^{1,2}$ and Joon Heo ${ }^{1, *}$ \\ Received: 21 September 2015; Accepted: 3 December 2015; Published: 9 December 2015 \\ Academic Editors: Sisi Zlatanova and Kourosh Khoshelham \\ 1 School of Civil and Environmental Engineering, Yonsei University, 50 Yonsei-ro, Seodaemun-gu, \\ Seoul 120-749, Korea; netgo82@yonsei.ac.kr (S.K.); jhkim2014@yonsei.ac.kr (J.K.); \\ lionheart_kr@yonsei.ac.kr (J.J.) \\ 2 Department of Photogrammetry, University of Bonn, Nussallee 15, Bonn 53115, Germany; \\ j.jung@igg.uni-bonn.de \\ * Correspondence: jheo@yonsei.ac.kr; Tel.: +82-2-2123-5797; Fax: +82-2-2123-8209
}

\begin{abstract}
The cadastral system provides land ownership information by registering and representing land boundaries on a map. The current cadastral system in Korea, however, focuses mainly on the management of $2 \mathrm{D}$ land-surface boundaries. It is not yet possible to provide efficient or reliable land administration, as this 2D system cannot support or manage land information on 3D properties (including architectures and civil infrastructures) for both above-ground and underground facilities. A geometrical model of the 3D parcel, therefore, is required for registration of 3D properties. This paper, considering the role of the cadastral system, proposes a framework for a 3D underground cadastral system that can register various types of 3D underground properties using indoor mapping for as-built Building Information Modeling (BIM). The implementation consists of four phases: (1) geometric modeling of a real underground infrastructure using terrestrial laser scanning data; (2) implementation of as-built BIM based on geometric modeling results; (3) accuracy assessment for created as-built BIM using reference points acquired by total station; and (4) creation of three types of 3D underground cadastral map to represent underground properties. The experimental results, based on indoor mapping for as-built BIM, show that the proposed framework for a 3D underground cadastral system is able to register the rights, responsibilities, and restrictions corresponding to the $3 \mathrm{D}$ underground properties. In this way, clearly identifying the underground physical situation enables more reliable and effective decision-making in all aspects of the national land administration system.
\end{abstract}

Keywords: 3D underground cadastral system; indoor mapping; as-built BIM; terrestrial laser scanning

\section{Introduction}

The International Federation of Surveyors (FIG) defines a cadaster as follows: it "is normally a parcel based and up-to-date land information system containing a record of interests in land. It usually includes a geometric description of land parcels linked to other records describing the nature of the interests, and ownership or control of those interests, and often the value of the parcel and its improvements" [1]. In short, an important function of the cadastral system is to support the protection of ownership and provide spatial information by registering physical objects. Conventionally, the system is not linked to 3D properties but is mainly related to only 2D surface parcels themselves. 
However, due to population growth and shortage of available land, especially in urban areas, property development has been conducted extensively through both above-ground and underground spaces. This has incurred a variety of problems related to the registration and management of 3D properties based on a 2D cadastral system [2]. Thus, registration of 3D property rights has become an important issue in the cadastral domain, because it is a fundamental function for protection of ownership, property tax assessment, land use, and land management systems [3-5]. As such, it is used directly by land registries, certified public appraisers, real estate agents, city planners, and landowners. Thus too, validated 3D cadastral data has to be established and provided. Consequently, 3D cadastral system research and development continue to be critical land management issues, and Korea is no exception in this regard.

The issues impacting 3D underground property in Korea can be summarized as follows: boundary disputes from the ambiguity of the definition of scope of justifiable profit, administrative confusion in implementing the registration, management and utilization of underground space, double compensation problem, and the lack of adequate plans and systematic registration for underground architectures and civil infrastructures. These problems are occurring under the lack of specific laws and regulations for registering and managing underground properties [6-10]. In this light, the main purpose of the present study was to devise new concepts for the 3D underground cadastral system by adopting the indoor mapping method used for as-built Building Information Modeling (BIM) [11-13]. This investigation originated from our preceding studies on productive high-complexity 3D city modeling of building exteriors and productive modeling for development of as-built BIM of indoor structures [14,15]. These were mainly focused on the modeling of building components in the construction management domain. However, in the present paper, a method of $3 \mathrm{D}$ underground cadastral mapping based on indoor mapping for as-built BIM is proposed. This method represents a new-concept mapping framework for 3D underground properties in the cadastral domain. The remainder of this paper is structured as follows. In Section 2, a review of the literature on the 3D cadastral system and indoor mapping for as-built BIM is conducted. In Section 3, an overall 3D underground cadastral system development procedure consisting of the following four steps is proposed: (1) geometric modeling of underground construction components; (2) as-built BIM in Revit software; (3) accuracy assessment of as-built BIM; and (4) creation of 3D underground cadastral maps for the 3D underground property. In Section 4, the implementation of the proposed method in a real underground infrastructure for creation of 3D underground cadastral maps using as-built BIM data is presented. In Section 5, conclusions are drawn and future work is anticipated.

\section{Related Work}

The 3D cadastre "registers and gives insight into right and restrictions not only on 2D parcels, but also on 3D property units" [16]. Required for the establishment and management of a 3D cadastre are 3D property registration laws, 3D data acquisition methods, 3D spatial database management systems, and a functional 3D visualization platform [17]. 3D data acquisition and efficient data processing related to registration of 3D properties, not only for above-ground but also for underground spaces, are crucial land administration steps in the determination and management of legal information with respect to rights, responsibilities, and restrictions.

In numerous cadastral-domain studies, a variety of methodological approaches, namely range-based modeling, image-based modeling, and some integrated approaches, have been employed for mapping and registration of 3D properties [18]. The most widely utilized method for acquiring 3D properties is terrestrial laser scanning, owing to its relative ease of application to $3 \mathrm{D}$ feature extraction $[14,15,19-27]$. Image-based modeling offers advantages including lower cost, faster data acquisition, and less manpower required for extraction of land-parcel boundaries and external building components [28-33]. Its disadvantages, however, are its unsuitability for irregularly shaped or complex construction, low-light conditions, and oblique-viewing-angle sites [34]. Over the past decade, integrated range-based and image-based modeling have been developed by means of 
aerial laser scanning and aerial photogrammetry [35-38] as well as the integration of terrestrial laser scanning and terrestrial photogrammetry [19,39-41].

Most of these methods, unfortunately, are designed for extraction and reconstruction only of external building information; that is, they are effective only for 3D above-ground cadastral systems, and are not well customized to 3D underground cadastral systems. Interior mapping for $3 \mathrm{D}$ underground cadastre is opposite to exterior mapping for 3D above-ground cadastre. In that context, interior mapping, which is officially termed "indoor mapping", is an indispensable step for the representation of various types of 3D underground properties.

Indoor mapping, depicting fundamental building components such as floors, walls, and ceilings, is becoming more commonly used for as-built BIM. It has emerged as a powerful tool for compiling information on actual building conditions and modeling accordingly [11-13,27]. With regard to the operation and maintenance (O\&M) of architectures and civil infrastructures, it has been proven that as-built BIM can improve the efficiency of building and facility management by providing for building safety, building lifespan, sustainable management, space management, maintainability, and control of energy consumption [42]. However, the procedure of 3D as-built BIM for buildings and facilities remains heavily reliant on manual processing, not only of geometric but also semantic information [22,43,44]. In order to overcome the inefficiencies of manual geometric processing, in 3D as-built BIM, photogrammetry and terrestrial laser scanning have become more commonly utilized for geometric data acquisition of 3D features than conventional surveying equipment such as total station and measurement tapes [45]. In the as-built BIM field, photogrammetry can be used to generate 3D building reconstructions based on image processing and computer-vision methodologies. Nonetheless, it has limitations, especially for building interiors, due to problems including the lack of feature extraction from non-textured surfaces, complex geometric conditions, and lighting conditions [45,46].

Terrestrial laser scanning can generate point clouds with a large number of points containing abundant 3D location information. It has some disadvantages, however, such as cost, maintenance, and, not least, the size of the acquired point cloud data. On the other hand, it is very accurate, offers high resolution, and is not sensitive to light conditions [47]. Most notably, it can handle sharp corners and edges, which is critical for as-built BIM [48]. For that reason, terrestrial laser scanning is considered the most suitable method —and indeed is the prevailing choice-for modeling of complex geometric buildings [13,18,45,49-51].

In this research, a framework for 3D underground cadastral system based on data acquisition with terrestrial laser scanning and 3D underground property mapping with an indoor mapping method designed for as-built BIM is proposed.

\section{Proposed Method}

\subsection{Overviews}

A 3D underground cadastral system based on indoor mapping methodology developed for as-built BIM is proposed. The four data processing steps are as follows: (1) geometric modeling of underground properties; (2) as-built BIM in Revit software; (3) accuracy assessment; and (4) creation of 3D underground cadastral map based on as-built BIM. In the geometric modeling step, the plane components are extracted from point clouds by RANdom SAmple Consensus (RANSAC) segmentation [52-54]. Then, the refinement process is applied for removal of noise and boundary tracing. In the as-built BIM step, the geometric modeling is imported into BIM software to create as-built BIM, after which an accuracy assessment is conducted. In this accuracy assessment step, control-points surveying and targets acquisition are conducted to evaluate the quality of as-built BIM. In the 3D underground cadastral map creation step, an isometric view of the 3D underground cadastral map, a 2D surface parcel with footprints of the 3D underground cadastral map, and a 
3D surface and 3D underground cadastral map are produced in order to register 3D underground properties. Figure 1 illustrates the method's overall procedure.

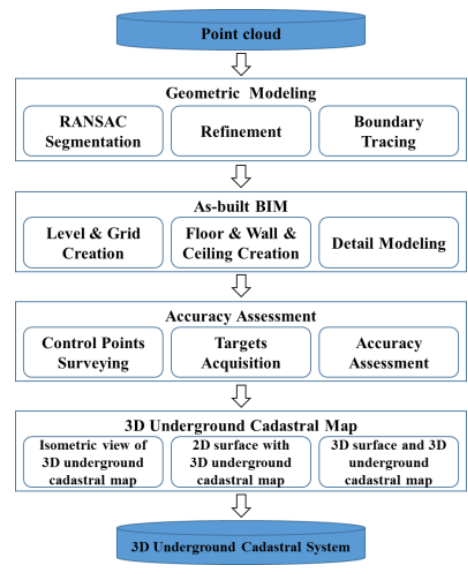

Figure 1. Overall procedure of proposed method.

\subsection{Geometric Modeling}

The methodology of geometric modeling, derived in our previous research, consists of three phases: (1) segmentation; (2) refinement; and (3) boundary tracing [14,15]. In the segmentation phase, plane components are identified and directly extracted from point clouds in the polygon type. This is the initial and most important step in 3D as-built BIM. In the present study, the RANSAC algorithm [54], among a variety of segmentation algorithms including Hough transform [55], Gaussian sphere [56], Expectation Maximization (EM) [57], tensor voting [58], region growing [59], and others, was selected for identification and extraction of plane components due to its ability to extract a variety of different shapes of planes, not to mention the fact that it is the most widely used and robust segmentation method with respect to noisy data [53,60-62]. RANSAC was originally proposed for robust fitting of a model from a dataset containing significant gross errors. It consists of inliers that can be represented by a set of model parameters and outliers that do not fit the model. RANSAC includes a hypothesis step and a test step. To achieve the best results, the two steps are iteratively processed until the number of iterations $(k)$ is reached. Iteration $(k)$ can be described by Equation (1):

$$
k=\frac{\log (1-p)}{\log \left(1-w^{n}\right)}
$$

where $p$ is the probability that all randomly selected points are inliers, $n$ is the number of samples selected in the hypothesize step, and $w$ is the likelihood ratio that a point belongs to the best plane. The Root Mean Squared Error (RMSE) can be used to determine the best planes. The RMSE can be described by Equation (2):

$$
R M S E=\sqrt{\sum_{i=1}^{N}\left(\frac{\left|a x_{i}+b y_{i}+c z_{i}+d\right|}{\sqrt{a^{2}+b^{2}+c^{2}}}\right)^{2} \cdot \frac{1}{N}}
$$

where $(x, y, z)$ are Cartesian coordinates of a point, $(a, b, c, d)$ is a parameter vector on the 3D plane, and $N$ is the number of points in set $X$.

Based on the RANSAC segmentation method, a variety of planes are extracted. However, noisy points, which are mis-classification results, can also be extracted through RANSAC processing. In order to solve this problem, a labeling method is used to filter erroneously segmented planes. The model plane with inlier points, extracted by RANSAC, is rotated and projected onto a binary image on the x-y plane. 
This binary image can be divided into two categories, occupied pixels (as " 1 ") and non-occupied pixels (as " 0 "). In this way, the labeling method determines the pixels' interconnectivity. Then, the connectivity of each plane component is labeled and its pixels are counted [63]. Finally, the largest area of the binary image remains, and the others, considered as noise, are removed. Figure 2 provides a conceptual illustration of the refinement process.
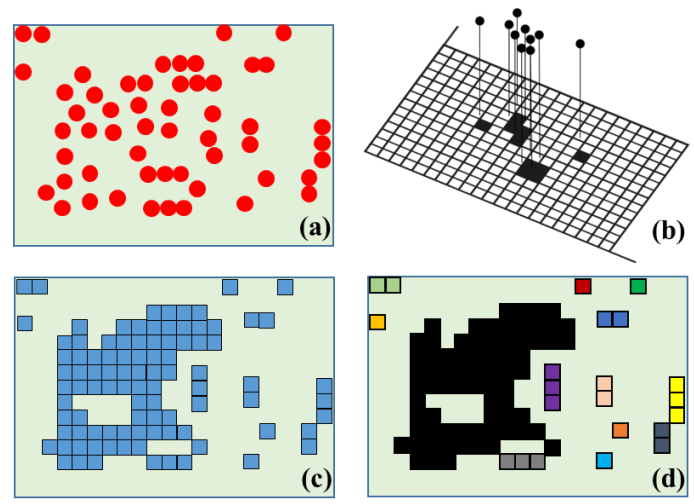

Figure 2. Conceptual illustration of the refinement process: (a) Inlier points of model plane; (b) Projection of points on plane; (c) Rasterized image; (d) Result of image labeling (gray-colored area is integrated into the largest black-colored area; the other colored areas, such as yellow, green, blue, etc., are considered to be noise). (Figure is adopted from [15]).

In the boundary tracing step, the boundary pixels are traced out only from the occupied pixels. In order to do that, it begins with from the top left occupied pixel in the binary image. Then, the next adjacent boundary pixels are checked to link between each pixel through consistent processing in the clockwise direction. In order to create a boundary of hole components including gates and open doors, the original binary image has to be inversed to represent these kinds of spaces as 1 and the others, which are the original binary image spaces, as 0 . Then, the same processes of labeling and boundary tracing are conducted for each of the empty and opened spaces. Finally, traced-out boundary features including the extracted plane are produced and returned to the original coordinates system inversely. Figure 3 illustrates the concept of boundary tracing.

For the refinement and boundary tracing steps, the grid cell size of the binary image has to be carefully defined for a series of raster processing. It directly affects the result of geometric modeling from point clouds. According to the recommendations of the previous study and several experiments for the project site, $0.05 \mathrm{~m}$ is chosen as the optimal grid cell size [14,15].
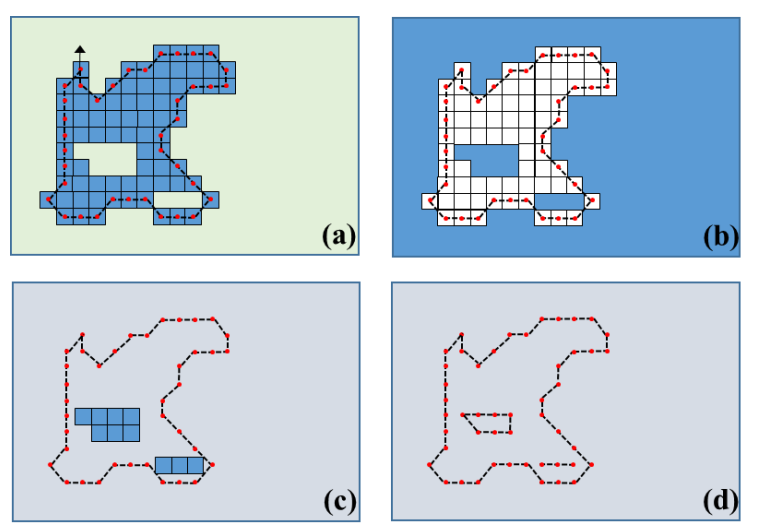

Figure 3. Boundary tracing and hollow objects detected by scheme: (a) Boundary tracing; (b) Inversion of binary raster image; (c) Hollow area detection by labeling; (d) Boundary tracing of hollow area (Figure is adopted from [15]). 


\subsection{As-Built BIM}

Based on the processing outlined above, 3D boundary lines and the remaining points, produced from the 3D point cloud, provide sufficient support to the modeler for efficient identification and modeling of building components. Compared with conventional direct 3D modeling, the proposed method increases productivity and enhances quality. Because the data size is reduced to $5 \%$ of the point cloud size or less, 3D boundary lines with topological relationships of plane features can be used mainly as reference data for the 3D as-built modeling. Moreover, without preprocessing, 3D modeling system failure can occur due to the gigantic size of point cloud data [14]. In this study, Autodesk Revit 2014 [64] was selected for the 3D as-built modeling. Finally, by using the geometric modeling method, the productivity of $3 \mathrm{D}$ as-built BIM is improved, especially by reducing the necessary human effort $[14,15]$.

\subsection{Accuracy Assessment}

To evaluate the quality of the as-built BIM, accuracy assessment is conducted by comparison with designated target points. In this study, accuracy assessment consisted of three phases: (1) control-point surveying; (2) target-coordinate acquisition; and (3) accuracy assessment.

Control-point surveying establishes a consistent and accurate network of physical features on the ground, and defines the geographic positions of project sites. This network consists of a vertical reference network and a horizontal reference network. The vertical reference network is established using leveling, and the horizontal reference network by using total station to tie all of the control points by angle and distance. Then, target-coordinate acquisition is conducted by total station, which is radial surveying based on established control points. In order to accomplish that, target points have to be well-defined points such as crossing edges of building components, and they have to be evenly-distributed for overall geometric accuracy. Finally, the acquired target points are assessed according to the Euclidean average distance error, Root Mean Square Error (RMSE), and Spherical Accuracy Standards (SAS).

\subsection{Concepts of 3D Underground Cadastral Map}

The fundamental purpose of the cadastral system is to support the registration of a title with a legally binding digital cadastral map [65]. Currently, most of cadastral systems are still maintained in the 2D cadastral map format $[5,66]$. For that reason, this study suggests three types of 3D underground cadastral mapping to identify and prove the physical status of 3D underground parcels with (1) an isometric view of the 3D underground cadastral map [17,67,68]; (2) a 2D surface parcel with footprints of the 3D underground cadastral map [2,69,70]; and (3) a 3D surface and 3D underground cadastral map [71-75].

The isometric view of the 3D underground cadastral map is used to describe the geometric information of a 3D underground parcel separately from the surface parcel. This map describes the volume of 3D underground property in the cadastral system. It is able to register spatial information details such as the coordinates of boundary corner points, boundary distances, planimetric areas, and volumes of given underground property. Thus, it can deal with a variety of information, including rights, restrictions, and responsibilities, related to 3D underground property.

A 2D surface parcel with footprints of the 3D underground cadastral map is used to represent the $3 \mathrm{D}$ underground property with corresponding surface parcels. It is able to verify the ownership between underground parcels and surface parcels in order to prevent vertical land disputes and to provide better public land administration. Additionally, it can incorporate a 3D underground cadastral system with an existing 2D cadastral map, because most of the current land management systems, such as the Korea Land Information System (KLIS), the Urban Planning Information System (UPIS) [76], and the Land Use Regulations Information system (LURIS), are based on 2D cadastral maps [77]. 
A 3D surface and 3D underground cadastral map are used to represent the location of 3D underground properties with regard to real-world situations. They are able to register and manage depth information, which represents the difference between 3D surface and 3D underground property. Through accurate representation of 3D underground property, mapping can deal with land administration issues including underground ownership, underground compensation, and underground taxation. Thereby, it can support the various stakeholders in establishing, supporting, and maintaining their legal rights over 3D underground property.

\section{Application}

The proposed methodology described in the previous section was implemented in a real underground infrastructure in order to create a 3D underground cadastral map.

\subsection{Project Site and Data Acquisition}

The project site is the Gangnam subway station on Seoul Metro subway line 2 in Seoul, Korea. Gangnam subway station is the busiest subway station among the 119 stations in Seoul. Its average daily traffic is 135,642 people/day [78]. This station consists of two floors: the first-floor underground shopping mall includes circulation space, a number of stores, public spaces such as lounges and restrooms, and facility management spaces such as mechanical facility rooms, storage rooms, management offices, and disaster prevention facilities; the second underground floor is the subway platform. In this study, due to the limitations of as-built surveying (such as restriction of access to facility management space and commercial space under the leasehold), the data acquisition focused mainly on the circulation space. For the rest of Gangnam subway station, floor plans were principally utilized.

Table 1. Point cloud acquisition and test environment specifications.

\begin{tabular}{|c|c|}
\hline Categories & Specifications \\
\hline Target Study Area & $\begin{array}{l}\text { Gangnam subway station: underground shopping center and } \\
\text { subway station platform (Gangnam-gu, Seoul, Korea) }\end{array}$ \\
\hline $\begin{array}{l}\text { Extent of Subway Station } \\
\text { (Along Centerline) }\end{array}$ & $\begin{array}{c}\text { Length }=254.116 \mathrm{~m} \\
\text { Width }=177.5 \mathrm{~m} \\
\text { Height }=7.05 \mathrm{~m} \\
\text { Scanner model: Leica Scan Station P20 }\end{array}$ \\
\hline $\begin{array}{c}\text { Type of Terrestrial Laser } \\
\text { Scanner }\end{array}$ & $\begin{array}{c}\text { 3D position accuracy: } 3 \mathrm{~mm} \text { at } 50 \mathrm{~m}, 6 \mathrm{~mm} \text { at } 100 \mathrm{~m} \\
\text { Linearity error: } \leqslant 1 \mathrm{~mm} \\
\text { Angular accuracy: } 8^{\prime \prime} \text { (horizontal/vertical) }\end{array}$ \\
\hline Laser Scanning Data & $\begin{array}{c}\text { Number of stations: } 171 \text { stations (1st floor: } 126,2 \text { nd floor: } 45) \\
\text { Data size: } 4.85 \text { GB } \\
\text { Number of points: } 106.7 \text { million }\end{array}$ \\
\hline Coordinate System & $\begin{array}{c}\text { Project coordinate system: Korea } 2000 \text { central belt } 2010 \\
\text { Datum: Korea } 2000 \text { (KGD2002) } \\
\text { Ellipsoid: GRS1980 }\end{array}$ \\
\hline Processing Environment & $\begin{array}{c}\text { Projection: Transverse Mercator } \\
\text { CPU: Intel }{ }^{\circledR} \text { Core }^{\mathrm{TM}} \text { i7-4790 CPU@3.60 GHz } \\
\text { RAM: } 32.0 \mathrm{~GB} \\
\text { OS: Windows } 7 \text { 64-bit }\end{array}$ \\
\hline Software & $\begin{array}{l}\text { Point cloud processing: Matlab 8.1.0 } \\
\text { As-built Modeling: Autodesk Revit } 2014\end{array}$ \\
\hline
\end{tabular}

Terrestrial laser scanning was conducted in the study area using Leica P20. In order to register point clouds of the Gangnam subway station into a Korean coordinate system, Global Position System (GPS) surveying was conducted for six control points that were set up at entrances of the subway station. The high-quality control points were also scanned and used to register into terrestrial laser scanning data of Gangnam subway station. The specifications of the subway station, coordinate 
system, surveying equipment, and methods are summarized in Table 1. Figure 4 illustrates the location information on the project site with a map and photos.

\subsection{Segmentation and Geometric Modeling}

The results for each step in the processing are illustrated in Figure 5. Figure 5a shows the registered point clouds, and Figure 5a-1 shows the scanned point cloud of the selected area indicated by the dotted lines in Figure 5a. Figure $5 \mathrm{~b}$ shows the results for each of the segmented planes in different colors, and Figure $5 b-1$ shows the segmented planes of the selected area. Meanwhile, Figure $5 \mathrm{c}$ shows the $3 \mathrm{D}$ geometric modeling produced from the RANSAC algorithm described in the previous section, and Figure $5 c-1$ shows geometric modeling of the selected area. Geometric modeling can support modelers in enhancing the effectiveness and efficiency of as-built BIM, since it can precisely represent the boundaries and locations of building components. Consequently, the role of geometric modeling has a decisive effect on overall as-built modeling productivity with respect to both modeling accuracy and modeling time [14,15].

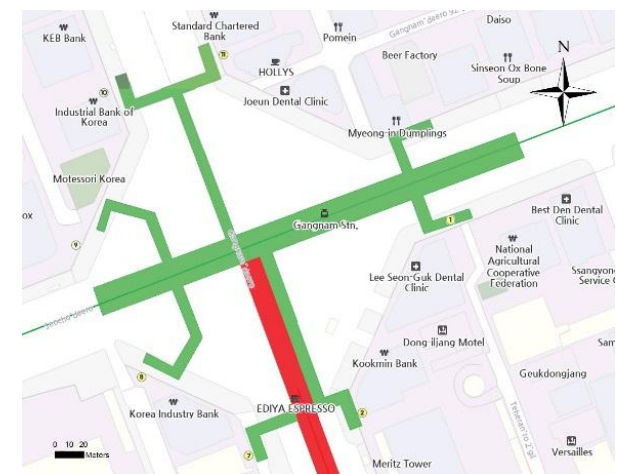

(a)

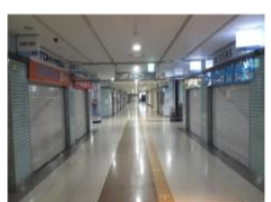

$(\mathrm{b}-1)$

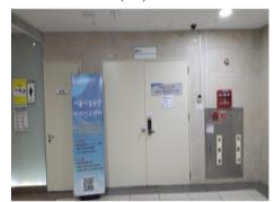

(b-3)

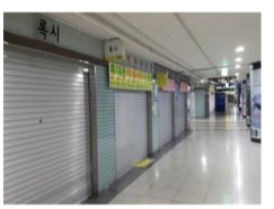

$(b-2)$

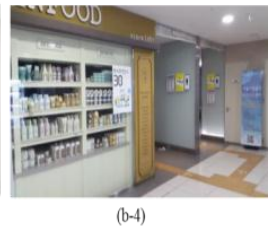

(b)

Figure 4. Project site: (a) study area; and (b-1, 2, 3, 4) Gangnam subway station underground shopping center; (b-1) circulation space; (b-2) store space; (b-3) facility management space; and (b-4) public restroom.
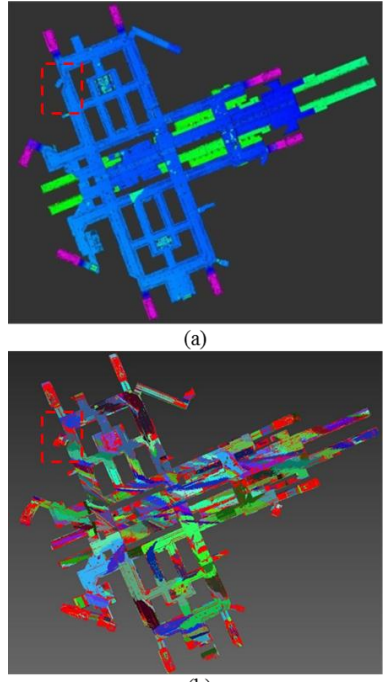

(b)

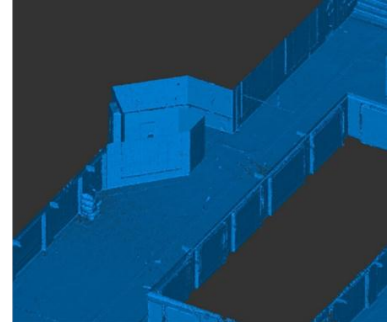

a-1)

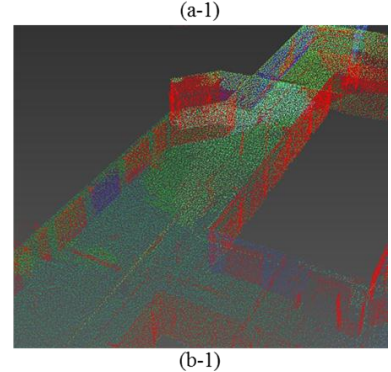

Figure 5. Cont. 


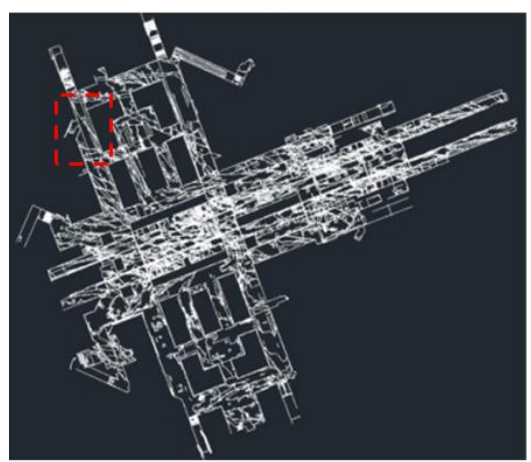

(c)

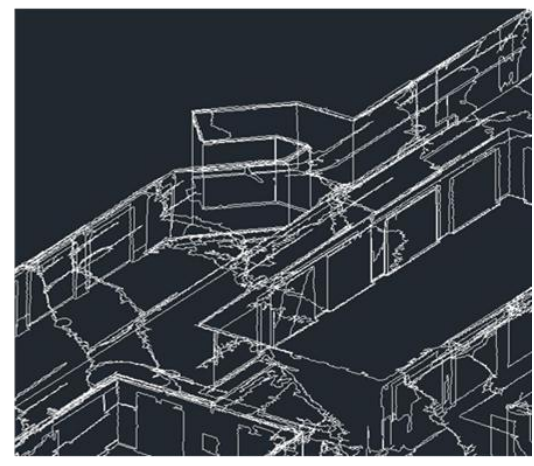

(c-1)

Figure 5. The result of each step in the processing: (a) Scanned point cloud; (a-1) Detailed description of (a); (b) Segmented planes; (b-1) Detailed description of (b); and (c) Geometric modeling; (c-1) Detailed description of (c).

\subsection{Implementation of As-Built BIM}

As-built BIM performs three main tasks: geometric modeling, assignment of object categories and material properties, and setting of relationships between components. These tasks do not have to be sequential; the sequence will depend on the workflow [49]. The main focus of the present study was the geometric modeling of as-built BIM for Gangnam subway station. This section explains how as-built BIM is achieved based on 3D geometric modeling. It is shown that the boundary lines extracted from 3D geometric modeling can support the identification of the shape of 3D building components.

For Gangnam subway station, the traced boundaries from the geometric modeling and remaining points were converted to AutoCAD DXF (Drawing Exchange Format) and then imported to Autodesk Revit for as-build BIM. The unique aspects of this study in relation to other as-built BIM research [14,15] are the following: (1) the purpose of modeling - the as-built modeling was focused on applying the 3D underground cadastral system, not just for building modeling, but also to register underground properties according to underground cadastral maps; (2) the extent of modeling-the extent of the study area was large compared with previous studies; (3) the accuracy assessment of modeling-for use of as-built BIM to register an underground property into the cadastral system and, so, create a 3D underground parcel, accuracy assessment is a prerequisite.

In this study, Autodesk Revit 2014, commercial BIM software, was used to conduct as-built modeling. In Revit, creation of BIM products is divided into three steps: (1) setting the level and grid line; (2) creating walls, floor, and ceiling; (3) detail modeling. The level and grid line creation is the very beginning step to create as-built BIM. In this study area, Gangnam subway station, a total of eight height levels were defined from the specific horizontal planes by considering floors, stairs, and ceiling. For the grid line creation, the numerous grid lines were created mainly by considering the wall components for each floor. Then, the floors and walls were created based on the setup level and grid line. Figure 6 illustrates the creation of the level and grid line. Finally, detail modeling, including a total of eight staircases and the limitation area, was conducted. Figure 7 represents the wire-frame and solid types of created as-built BIM of Gangnam subway station.

\subsection{Accuracy Assessment of As-Built BIM Implementation}

In order to apply as-built BIM of Gangnam subway station to the 3D underground cadastral system, horizontal and vertical accuracy assessment was conducted for the project site. Accuracy assessment includes three phases: (1) control-point surveying; (2) target-coordinate acquisition; and (3) accuracy assessment. 
In the control-point surveying phase, the closed traverse and leveling network with 10 control points is designed with consideration of the given underground environment. For the adjustment of the horizontal observations with the traverse network, observations were made of the total station, and the compass rule was applied. The angular misclosure of the traverse was $-3{ }^{\prime \prime}$, and the linear misclosure was $0.007 \mathrm{~m}$. For adjustment of the vertical observations, electronic digital/bar-code leveling was used; the misclosure of the observations was $0.00043 \mathrm{~m}$. Table 2 summarizes the surveying equipment, and Figure 8 illustrates the distribution of the control points and given traverse network.
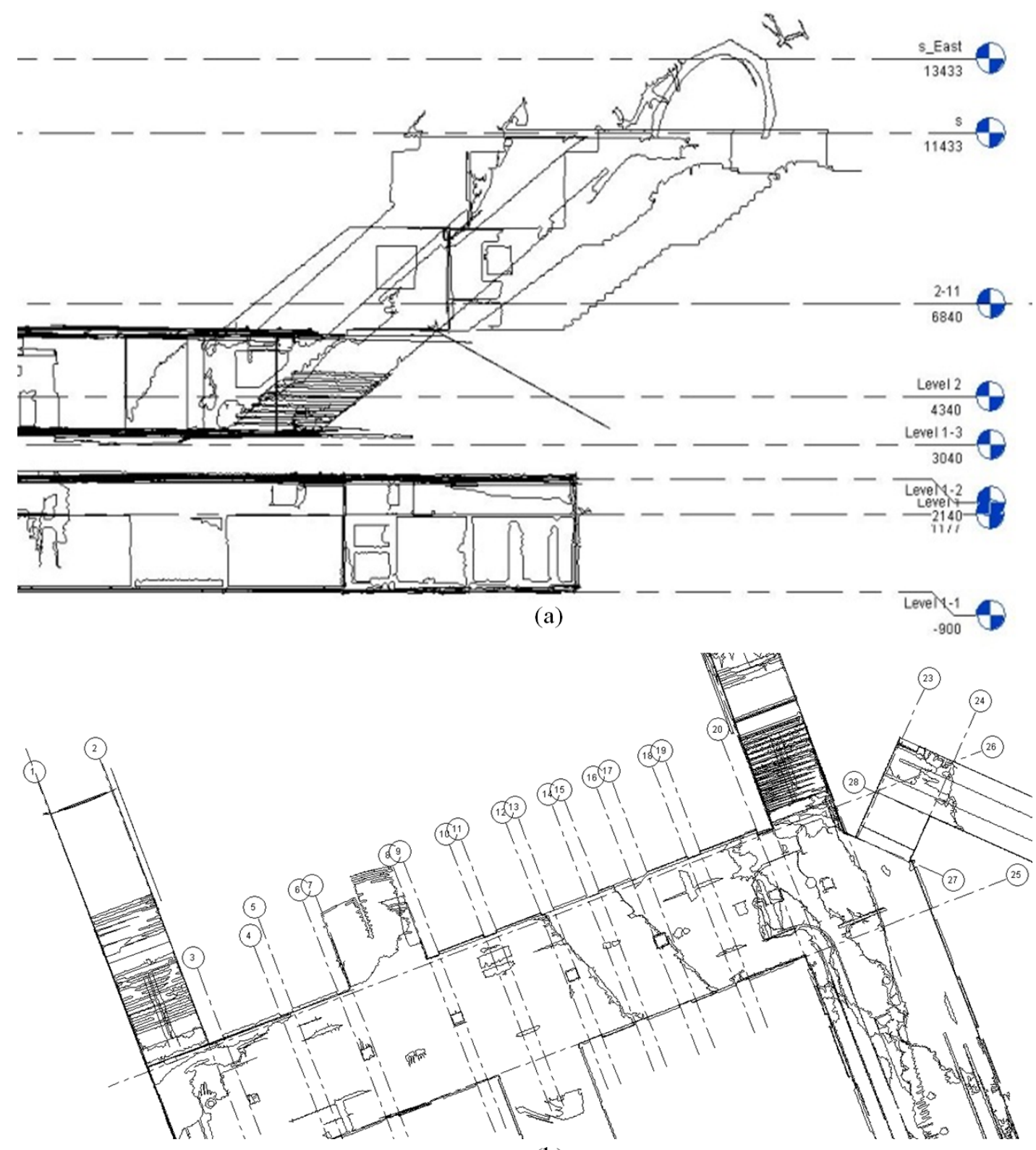

(b)

Figure 6. Level and grid line creation: (a) Created level line and (b) Created grid line. 


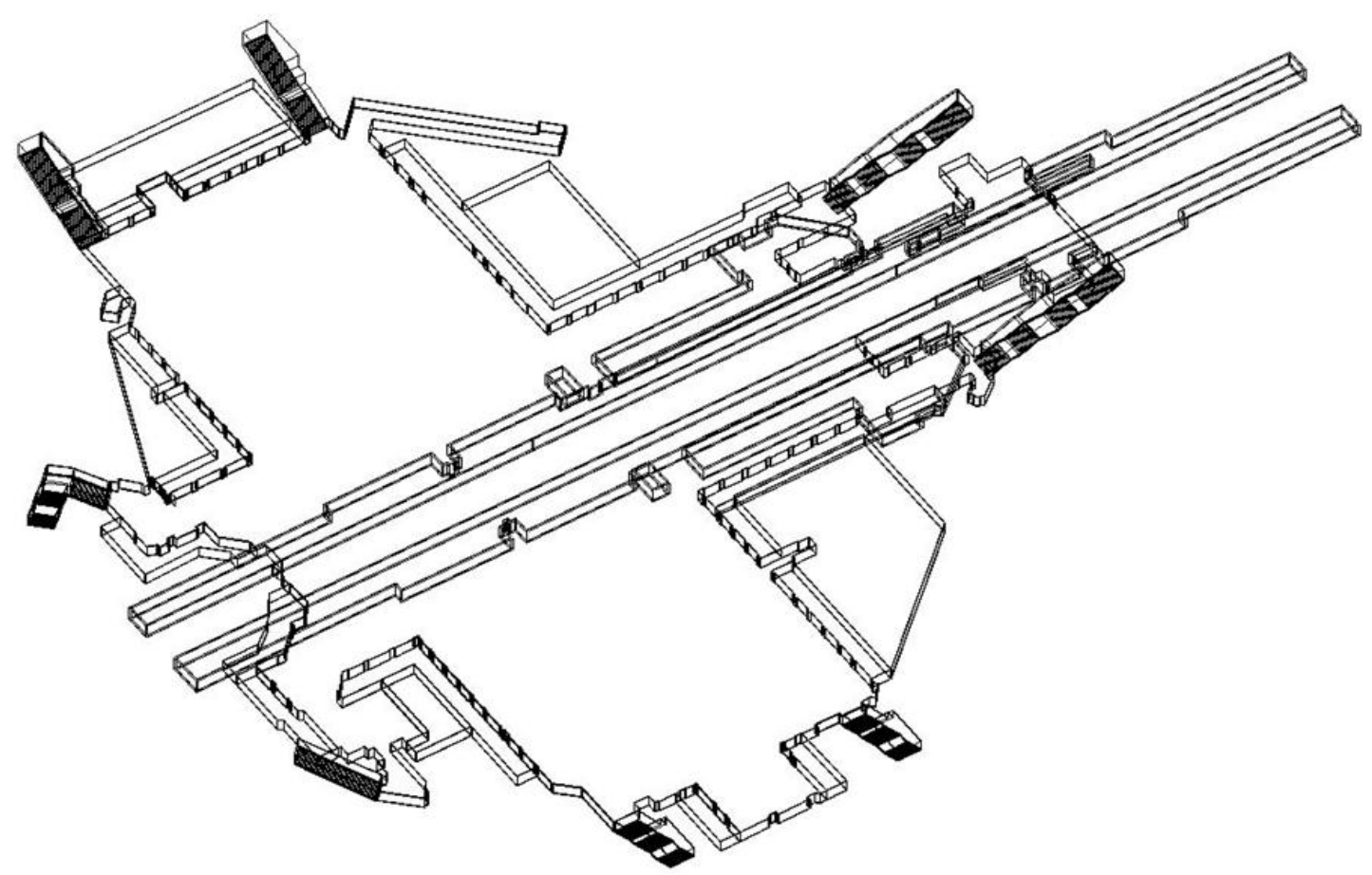

(a)

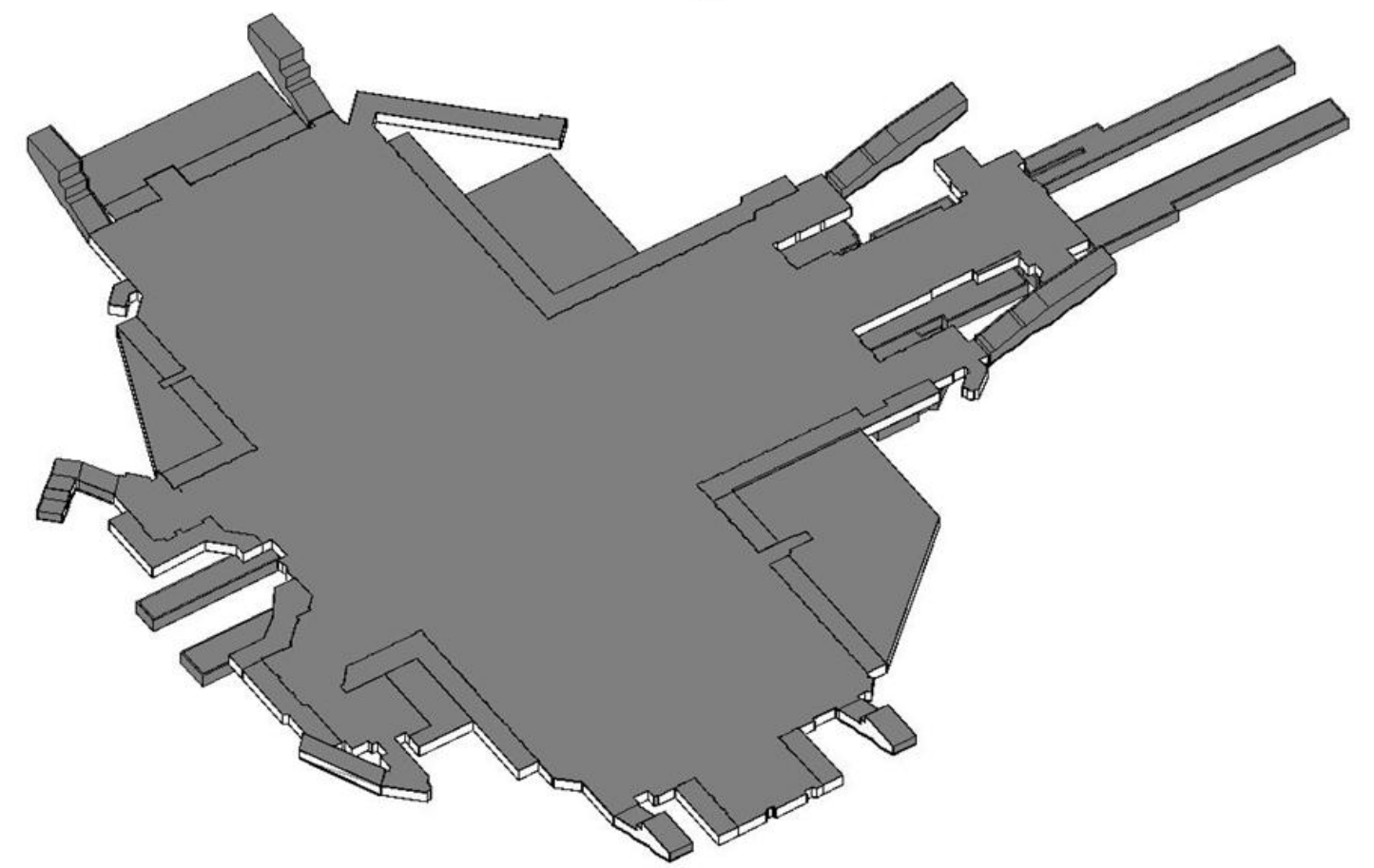

(b)

Figure 7. As-built BIM of Gangnam subway station: (a) Wire-frame type; (b) Solid type. 
Table 2. Specifications of total station and electronic digital/barcode level.

\begin{tabular}{cc}
\hline Equipment & Specifications \\
\hline & Model: GTS $9001 \mathrm{~A}$, Topcon \\
Total Station & 3D position accuracy: $3 \mathrm{~mm}$ at $50 \mathrm{~m}, 6 \mathrm{~mm}$ at $100 \mathrm{~m}$ \\
& Prism mode/linearity error: $\pm(2 \mathrm{~mm}+2 \mathrm{ppm} \times \mathrm{D})$ \\
& Non-prism mode/linearity error: $\pm(5 \mathrm{~mm})$ \\
Electronic Digital/Barcode Level & Model: Leica DNA 03 \\
& Accuracy of electronic measurement: $0.3 \mathrm{~mm}$ (invar staffs) \\
& Resolution height measurement: $0.01 \mathrm{~mm}$ \\
& Compensator-setting accuracy: $0.3^{\prime \prime}$ \\
& Single measurement time: typically 3 seconds \\
\hline
\end{tabular}

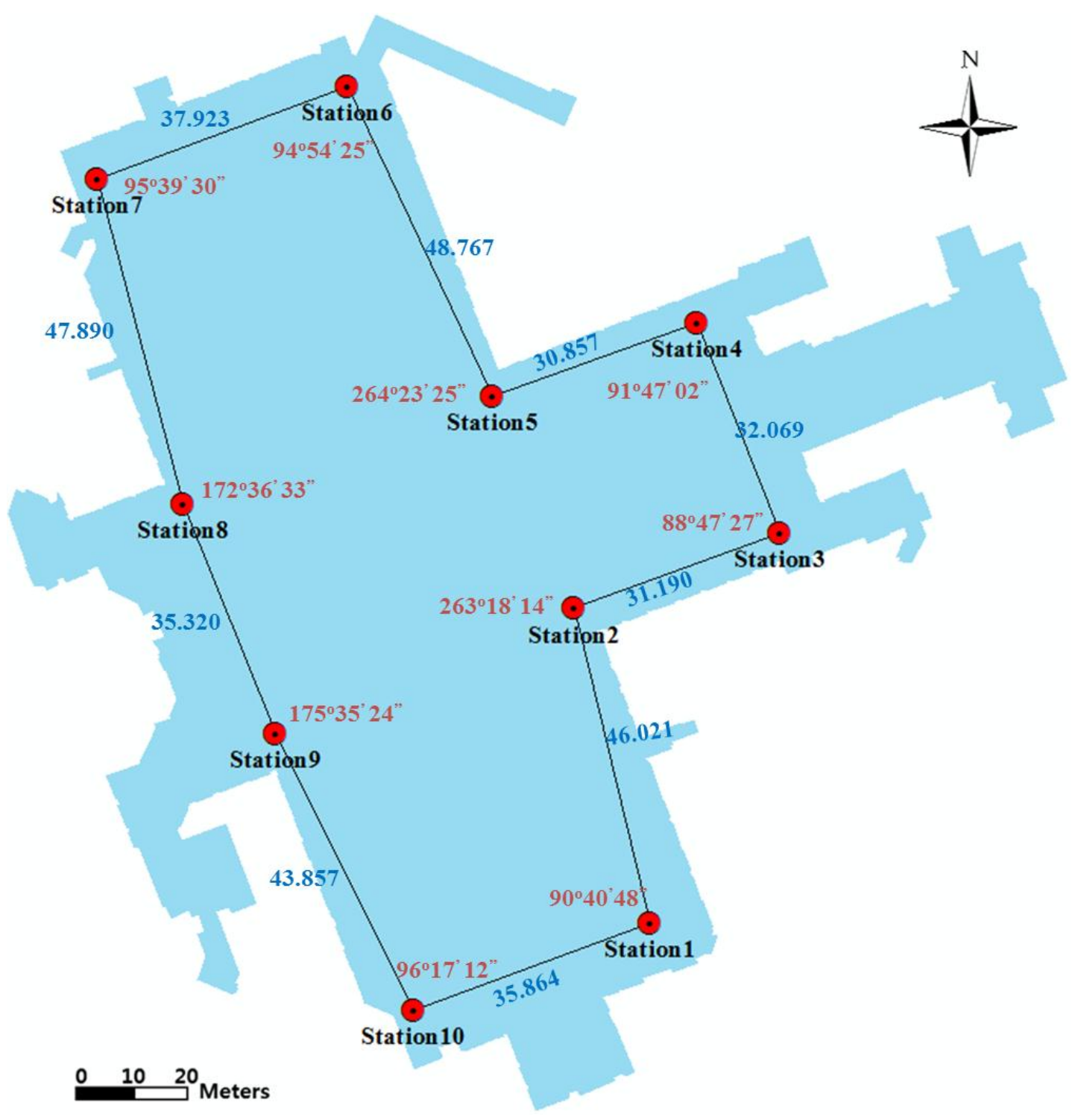

Figure 8. Distribution of control points and given traverse network.

For accuracy assessment, the surveyed reference points and corresponding as-built modeling points have to be prepared. In the present case, a total of 60 target points were selected for the accuracy assessment for the 3D as-built BIM of Gangnam subway station. They are well-defined points such as corners of walls on the floor and ceiling, and the reference coordinates were acquired 
by way of radial survey of the total station based on the $103 \mathrm{D}$ control points described in the above. Figure 9 illustrates the distribution of the 60 target points.

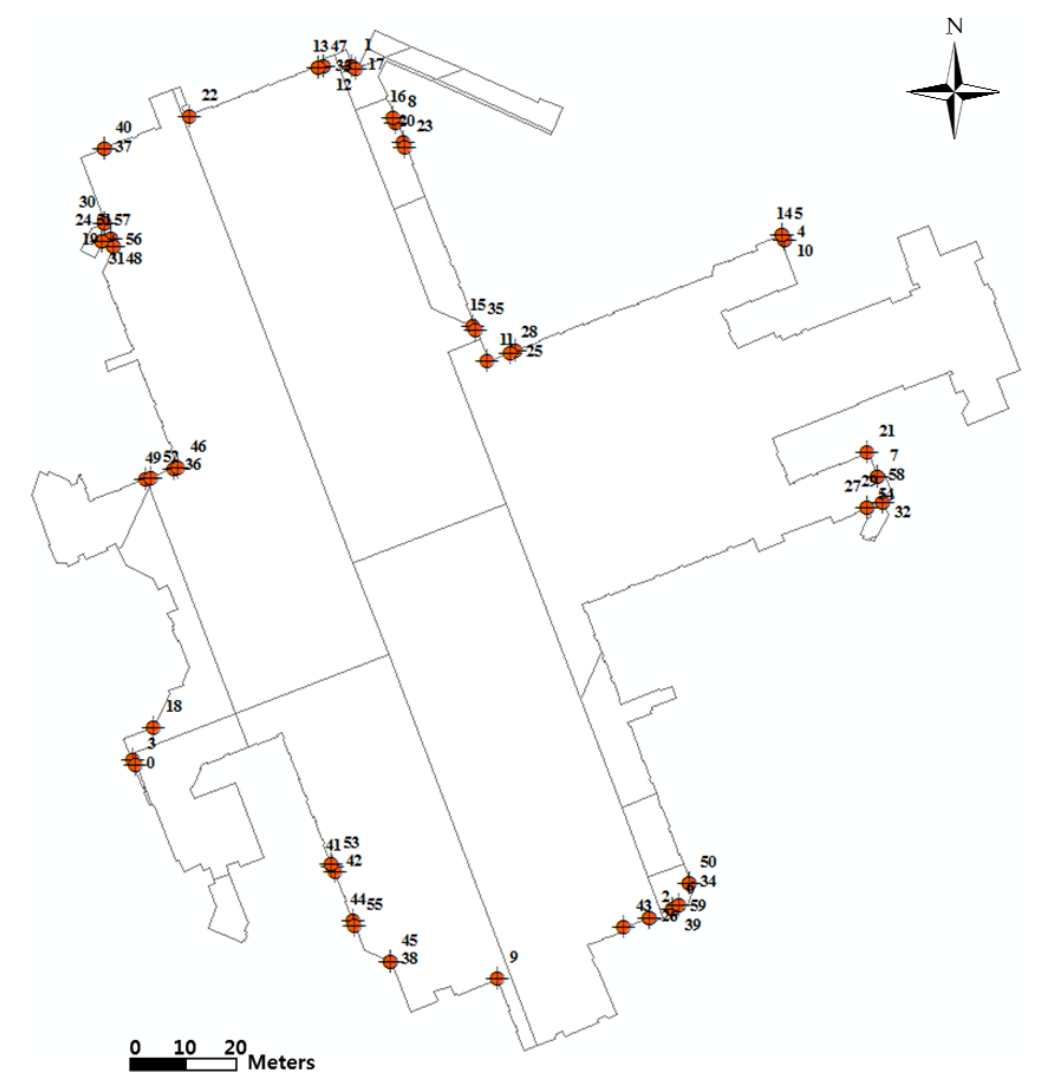

Figure 9. Distribution of 60 target points for accuracy assessment.

In the accuracy assessment step, the quality of the 3D wire-frame model from the as-built BIM was evaluated based on the acquired target points. To that end, the Euclidean average distance error $\left(\delta_{\text {avg }}\right)$ was assessed according to Equation (3):

$$
\delta_{\text {avg }}=\frac{1}{n} \sum_{i=1}^{n}\left|\mathrm{R} a_{i}-\mathrm{T}-b_{i}\right|
$$

where $a_{i}$ is the $i$-th point vector in the 3D wire-frame model, $b_{i}$ is the corresponding point vector measured by total station, $n$ is the number of point measurements, and $\mathrm{R}$ and $\mathrm{T}$ are the rotation and translation parameters, respectively, for 3D Helmert transformation (the scale was not considered in this comparison) [79]. The average error, thus calculated, indicated that the overall accuracy was $0.086 \mathrm{~m}$. According to Korea cadastral surveying regulations, the acceptable error tolerance in terms of Euclidean average distance error is $10 \mathrm{~cm}$ for a digital cadastral map, which records the boundaries of a 2D surface parcel by a set of coordinates ( $x$ and $y$ ) [80]. Even though the calculated Euclidean average distance error should be used only for the 2D surface parcel, it showed that the proposed 3D underground cadastral maps offered a level of accuracy within the allowable error tolerance.

Additionally, the RMSE and the SAS were computed. The RMSE was calculated by Equation (4):

$$
R M S E=\sqrt{\frac{1}{n} \sum_{i=1}^{n}\left(a_{i}^{t}-b_{i}\right)^{2}}
$$


where $a_{i}^{t}$ is the point transformed to total station coordinates. The calculated RMSE for Gangnam subway station was $0.095 \mathrm{~m}$; each direction $(x, y$, and $z)$ of the RMSEs are listed in Table 3 . The SAS, defined as the spherical radius of a 90\% probability sphere [81], was computed by Equation (5):

$$
S A S=0.833 \times\left(R M S E_{x}+R M S E_{y}+R M S E_{z}\right)
$$

as $0.129 \mathrm{~m}$, which represents the positional accuracy of the two generated 3D wire-frame models at the $90 \%$ confidence level.

\subsection{D Underground Cadastral Map}

Visualization and documentation of a land parcel directly affect protection of land ownership and decision-making in land administration. However, in Korea, the current cadastral map represents only 2D parcel boundaries, without any additional information related to $3 \mathrm{D}$ property such as representation of the property boundary. For that reason, this paper proposes three types of cadastral maps: (1) isometric view of 3D underground cadastral map; (2) 2D surface parcel with footprints of 3D underground cadastral map; (3) 3D surface and 3D underground cadastral maps, based on as-built BIM.

The isometric view of the 3D underground cadastral map plays the key role in obtaining a better understanding of the 3D geometry of an underground parcel. The isometric view should support three types of underground parcel map: (1) 3D underground internal boundary from as-built BIM, which is related to the internal boundary of the underground property; (2) "3D underground construction parcel" boundary, which is related to the exterior boundary of the underground property; and (3) "3D underground legal space parcel" boundary, which is related to the safety or restricted zone for protection of the underground construction boundary according to the Urban Railroad Act's "Compensation Criteria for Underground Land Use for Urban Railroad".

Figure 10 provides isometric views of the 3D underground cadastral map of Gangnam subway station: (a) 1st underground floor: Gangnam underground shopping mall; (b) 2nd underground floor: subway station platform; (c) Gangnam subway station with highlighted specific underground parcels; and (d) enlargement of specific underground parcels showing 3D underground parcel from as-built BIM (blue color), "3D underground construction parcel” boundary (red color) which attaches a $0.5 \mathrm{~m}$ thickness of wall, floor, and ceiling to the as-built BIM based on architectural drawing of Gangnam subway station, and "3D underground legal space parcel" boundary (green color) which attaches an additional $0.5 \mathrm{~m}$ thickness of "protection layer" to the "3D underground construction parcel" boundary by "Administrative Rules of the Railroad Construction Act on Compensation Criteria for the Underground Land Use for Railroad Construction" in Korea.

The area and volume of the underground shopping mall and subway station platform were calculated as attributes of the 3D underground properties. In the case of the underground shopping mall, the area and volume were $14,838.8 \mathrm{~m}^{2}$ and $38,580.8 \mathrm{~m}^{3}$, and in the case of the subway station platform, $3679.7 \mathrm{~m}^{2}$ and $15,086.9 \mathrm{~m}^{3}$ respectively.

In the case of the 2D surface parcel with footprints of the 3D underground cadastral map, the 3D underground subway station was divided into several parts according to the surface parcel boundaries in order to confirm the relationship between the 2D surface parcel and the 3D underground parcel. The Gangnam underground shopping mall is occupied by 26 surface parcels, of which 22 are owned by Seoul Metropolitan Government. The land categories are designated as "road". The remaining four parcels are privately owned, the land category of which is designated "building site". The ownership of these four private parcels had to be registered by sectional superficies to protect it. As another example, the subway station platform has been occupied by five surface parcels owned by Seoul Metropolitan Government, and the land categories are designated "road". Figure 11 illustrates the 2D footprint with 3D underground cadastral map. 
Table 4 provides detailed information on the relationship between the 2D surface parcel and the 3D underground parcel.

Table 3. Accuracy assessment results (unit: meters).

\begin{tabular}{|c|c|c|c|c|c|c|c|c|c|}
\hline \multirow{2}{*}{$\begin{array}{l}\text { Point } \\
\text { ID }\end{array}$} & \multicolumn{3}{|c|}{ Error Vector } & \multirow{2}{*}{ Error } & \multirow{2}{*}{$\begin{array}{l}\text { Point } \\
\text { ID }\end{array}$} & \multicolumn{3}{|c|}{ Error Vector } & \multirow{2}{*}{ Error } \\
\hline & $X$ & $Y$ & $\mathbf{Z}$ & & & $X$ & $\mathrm{Y}$ & $\mathbf{Z}$ & \\
\hline 1 & 0.119 & -0.054 & 0.091 & 0.160 & 31 & -0.049 & -0.012 & -0.088 & 0.101 \\
\hline 2 & 0.021 & 0.007 & 0.141 & 0.143 & 32 & -0.076 & -0.021 & -0.026 & 0.083 \\
\hline 3 & -0.067 & -0.131 & -0.085 & 0.170 & 33 & -0.022 & 0.027 & 0.051 & 0.062 \\
\hline 4 & 0.002 & 0.013 & -0.181 & 0.181 & 34 & -0.012 & 0.010 & 0.045 & 0.048 \\
\hline 5 & 0.005 & 0.018 & -0.174 & 0.175 & 35 & 0.012 & -0.017 & 0.050 & 0.054 \\
\hline 6 & -0.036 & 0.046 & 0.112 & 0.126 & 36 & -0.048 & 0.011 & -0.071 & 0.086 \\
\hline 7 & 0.078 & 0.106 & -0.087 & 0.158 & 37 & 0.063 & -0.001 & 0.016 & 0.065 \\
\hline 8 & -0.049 & 0.031 & 0.096 & 0.112 & 38 & -0.010 & -0.044 & 0.006 & 0.046 \\
\hline 9 & -0.031 & 0.102 & 0.053 & 0.119 & 39 & -0.003 & 0.032 & 0.042 & 0.052 \\
\hline 10 & 0.010 & 0.033 & -0.138 & 0.142 & 40 & 0.066 & 0.002 & -0.045 & 0.080 \\
\hline 11 & 0.095 & -0.042 & 0.047 & 0.115 & 41 & -0.044 & 0.017 & -0.004 & 0.047 \\
\hline 12 & -0.014 & 0.008 & 0.103 & 0.104 & 42 & -0.030 & -0.023 & 0.003 & 0.038 \\
\hline 13 & -0.010 & -0.004 & 0.102 & 0.102 & 43 & 0.033 & 0.009 & 0.033 & 0.047 \\
\hline 14 & 0.008 & 0.028 & -0.134 & 0.137 & 44 & -0.033 & 0.031 & -0.002 & 0.046 \\
\hline 15 & 0.021 & -0.007 & 0.097 & 0.099 & 45 & -0.008 & -0.037 & -0.053 & 0.066 \\
\hline 16 & 0.012 & -0.003 & 0.096 & 0.097 & 46 & -0.010 & 0.025 & -0.070 & 0.075 \\
\hline 17 & -0.024 & 0.004 & 0.095 & 0.098 & 47 & -0.013 & 0.008 & 0.032 & 0.036 \\
\hline 18 & 0.009 & -0.010 & -0.142 & 0.142 & 48 & 0.013 & -0.026 & -0.073 & 0.078 \\
\hline 19 & -0.091 & 0.044 & -0.030 & 0.106 & 49 & -0.005 & 0.015 & -0.070 & 0.072 \\
\hline 20 & -0.001 & -0.003 & 0.085 & 0.086 & 50 & -0.017 & -0.002 & -0.058 & 0.060 \\
\hline 21 & 0.008 & -0.090 & -0.020 & 0.093 & 51 & 0.001 & -0.035 & -0.061 & 0.070 \\
\hline 22 & 0.008 & -0.038 & 0.078 & 0.087 & 52 & 0.015 & 0.011 & -0.066 & 0.068 \\
\hline 23 & -0.016 & 0.000 & 0.084 & 0.086 & 53 & 0.029 & -0.021 & -0.007 & 0.037 \\
\hline 24 & 0.033 & 0.058 & -0.095 & 0.116 & 54 & -0.020 & -0.011 & 0.007 & 0.024 \\
\hline 25 & 0.012 & -0.051 & 0.062 & 0.081 & 55 & -0.006 & 0.017 & -0.006 & 0.019 \\
\hline 26 & 0.068 & -0.013 & 0.047 & 0.084 & 56 & 0.008 & -0.019 & 0.000 & 0.021 \\
\hline 27 & -0.001 & 0.014 & -0.115 & 0.116 & 57 & 0.005 & -0.030 & -0.022 & 0.038 \\
\hline 28 & 0.001 & -0.044 & 0.059 & 0.074 & 58 & 0.003 & 0.022 & -0.010 & 0.025 \\
\hline 29 & -0.082 & -0.023 & -0.015 & 0.086 & 59 & 0.043 & 0.006 & 0.035 & 0.056 \\
\hline 30 & 0.028 & 0.056 & 0.030 & 0.069 & 60 & -0.002 & 0.006 & 0.121 & 0.121 \\
\hline \multicolumn{6}{|c|}{ Average Error } & - & - & - & 0.086 \\
\hline \multicolumn{6}{|c|}{ RMSE } & 0.039 & 0.038 & 0.078 & 0.095 \\
\hline \multicolumn{6}{|c|}{ SAS } & - & - & - & 0.129 \\
\hline
\end{tabular}



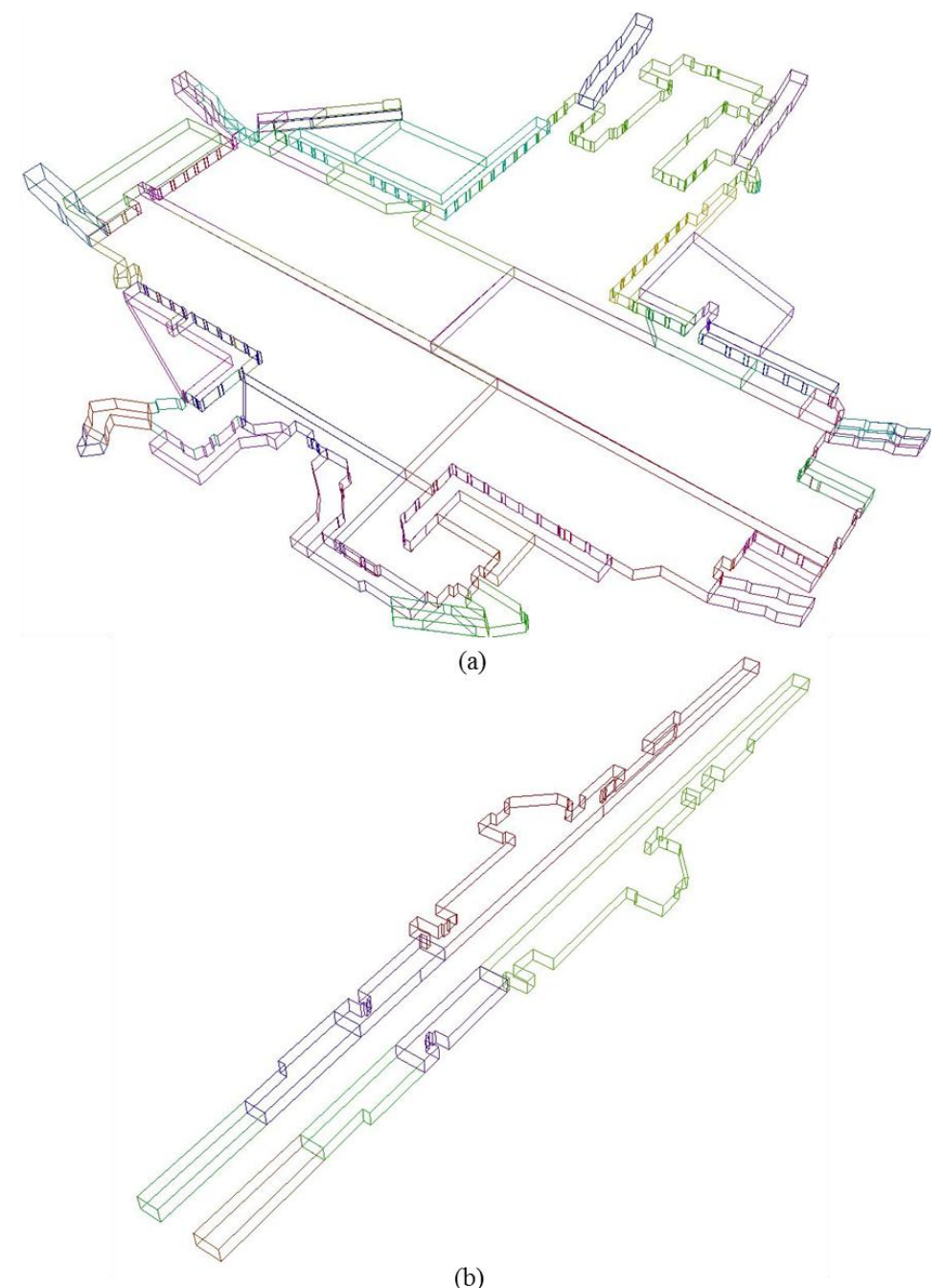

(b)

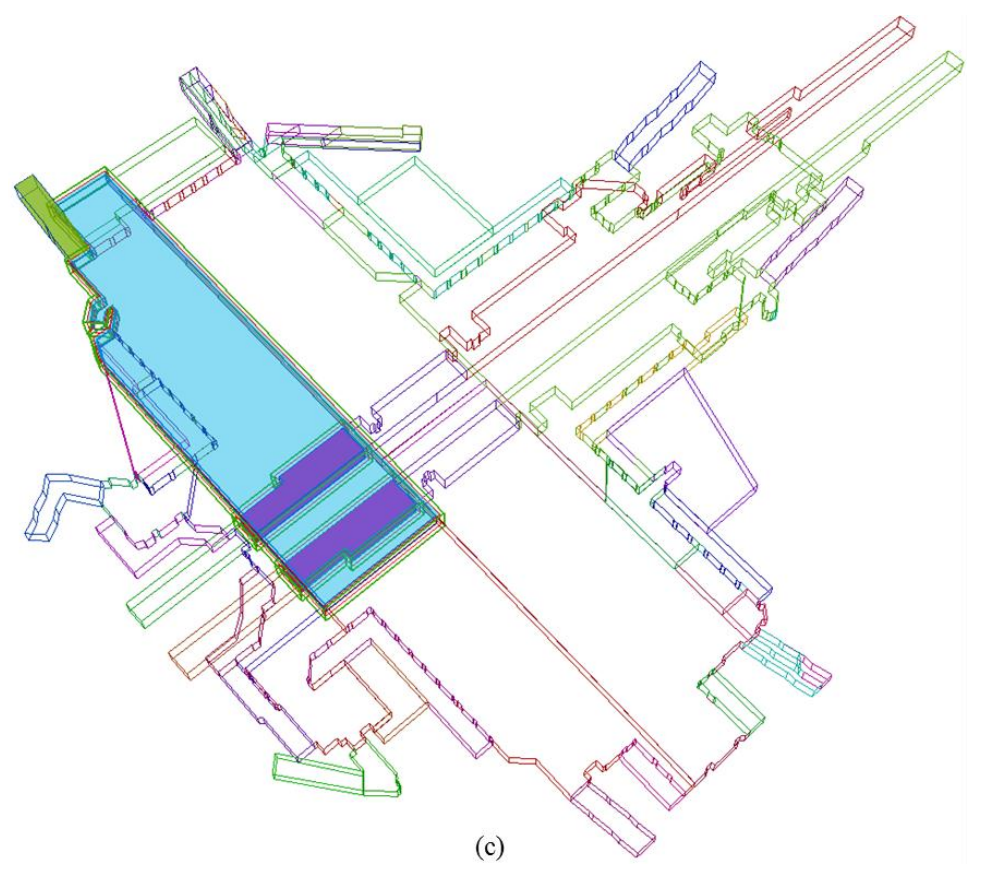

Figure 10. Cont. 


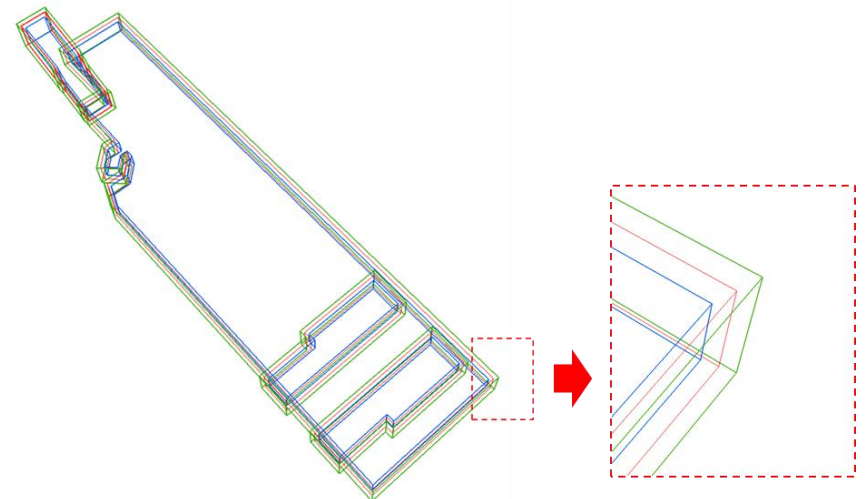

(d)

Figure 10. Iso metric view of 3D underground cadastral map in Gangnam subway station: (a) 3D underground construction parcel boundary of 1st underground floor: Gangnam underground shopping mall; (b) 3D underground construction parcel boundary of 2nd underground floor: subway station platform; (c) 3D underground construction parcel boundary of Gangnam subway station with highlight on particular underground parcels; and (d) 3D underground internal boundary (blue), 3D underground construction parcel boundary (red), and 3D underground legal space parcel boundary (green).
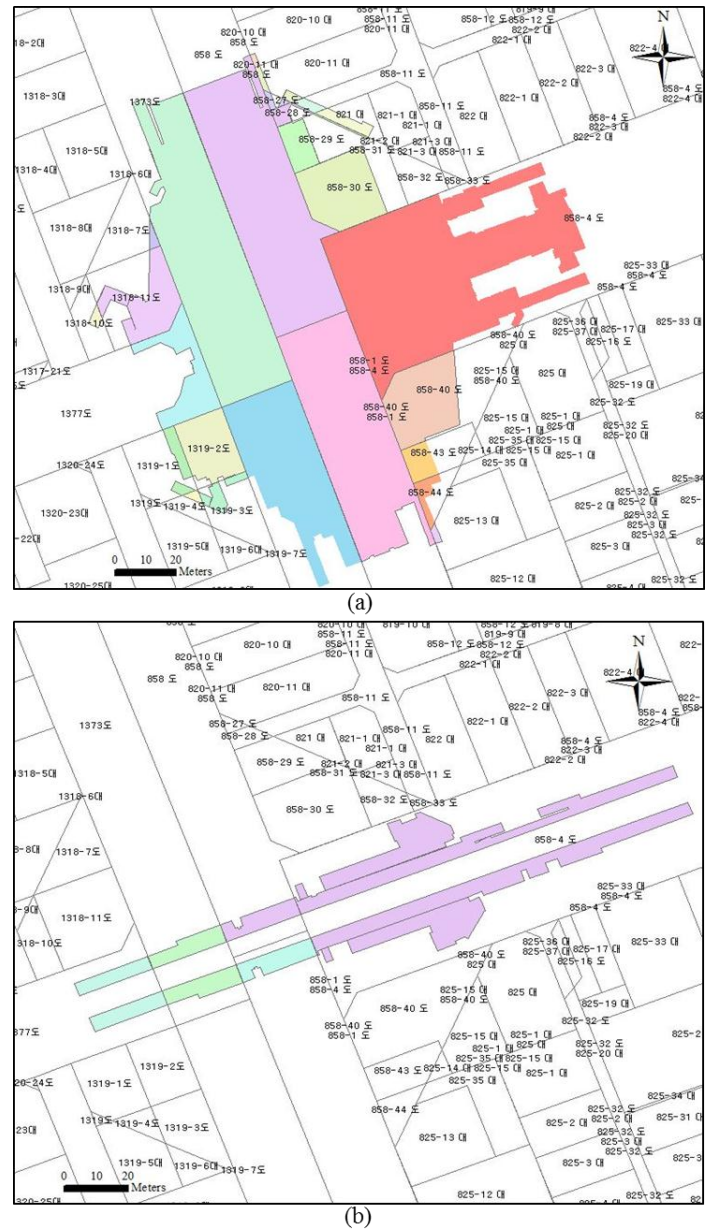

Figure 11. 2D surface parcel with footprints of 3D underground cadastral map in Gangnam subway station: (a) 1st underground floor: Gangnam underground shopping mall; and (b) 2nd underground floor: subway station platform. 
Table 4. Relationship between 2D surface parcel and 3D underground parcel.

\begin{tabular}{|c|c|c|c|c|c|c|c|}
\hline \multicolumn{2}{|c|}{ 2D Surface Parcel } & \multicolumn{6}{|c|}{ 3D Underground Parcel } \\
\hline $\begin{array}{c}\text { Parcel } \\
\text { Number }\end{array}$ & $\begin{array}{c}\text { Land } \\
\text { Category }\end{array}$ & $\begin{array}{l}\text { Underground } \\
\text { Parcel Number }\end{array}$ & Utiliza-tion & Ownership & Right & Area $\left(m^{2}\right)$ & Volume $\left(\mathrm{m}^{3}\right)$ \\
\hline $858-4$ & Road & $858-4-1$ & US & SMG & $\mathrm{FO}$ & 3475.3 & 9035.8 \\
\hline $858-40$ & Road & $858-40-1$ & US & SMG & $\mathrm{FO}$ & 610.2 & 1586.4 \\
\hline $858-43$ & Road & $858-43-1$ & US & SMG & $\mathrm{FO}$ & 116.4 & 302.7 \\
\hline $858-44$ & Road & $858-44-1$ & US & SMG & $\mathrm{FO}$ & 82.7 & 215.1 \\
\hline $825-13$ & Building site & $825-13-1$ & US (Exit) & Private land & SS & 21.9 & 56.9 \\
\hline $858-1$ & Road & $858-1-1$ & US & SMG & $\mathrm{FO}$ & 1956.2 & 5086.1 \\
\hline 1374 & Road & 1374-0-1 & US & SMG & $\mathrm{FO}$ & 1380.5 & 3589.2 \\
\hline $1319-3$ & Road & 1319-3-1 & US & SMG & $\mathrm{FO}$ & 107.1 & 278.5 \\
\hline $1319-4$ & Road & $1319-4-1$ & US & SMG & $\mathrm{FO}$ & 23.2 & 60.3 \\
\hline $1319-1$ & Road & 1319-1-1 & US & SMG & $\mathrm{FO}$ & 119.3 & 310.3 \\
\hline 1319-2 & Road & 1319-2-1 & US & SMG & $\mathrm{FO}$ & 377.4 & 981.1 \\
\hline 1377 & Road & $1377-0-1$ & US & SMG & $\mathrm{FO}$ & 430.7 & 1119.8 \\
\hline $1318-10$ & Road & $1318-10-1$ & US & SMG & $\mathrm{FO}$ & 33.9 & 88.0 \\
\hline 1318-11 & Road & 1318-11-1 & US & SMG & $\mathrm{FO}$ & 442.9 & 1151.5 \\
\hline 1318-7 & Road & $1318-7-1$ & US & SMG & $\mathrm{FO}$ & 29.1 & 75.6 \\
\hline 1373 & Road & $1373-0-1$ & US & SMG & $\mathrm{FO}$ & 2377.6 & 6181.8 \\
\hline 858 & Road & $858-0-1$ & US & SMG & $\mathrm{FO}$ & 2220.2 & 5772.5 \\
\hline $820-10$ & Building site & $820-10-1$ & US (Exit) & Private land & SS & 15.0 & 39.0 \\
\hline $820-11$ & Building site & $820-11-1$ & US (Exit) & Private land & SS & 51.7 & 134.4 \\
\hline $858-11$ & Road & 858-11-1 & US & SMG & $\mathrm{FO}$ & 34.8 & 90.4 \\
\hline 821 & Building site & $821-0-1$ & US (Exit) & Private land & SS & 80.4 & 208.9 \\
\hline $858-29$ & Road & $858-29-1$ & US & SMG & $\mathrm{FO}$ & 200.5 & 521.4 \\
\hline $858-30$ & Road & $858-30-1$ & US & SMG & $\mathrm{FO}$ & 565.5 & 1470.3 \\
\hline $858-28$ & Road & $858-28-1$ & US & SMG & $\mathrm{FO}$ & 51.8 & 134.6 \\
\hline $858-32$ & Road & $858-32-1$ & US & SMG & $\mathrm{FO}$ & 10.6 & 27.5 \\
\hline $858-27$ & Road & $858-27-1$ & US & SMG & $\mathrm{FO}$ & 24.1 & 62.6 \\
\hline 1373 & Road & $1373-0-2$ & SP & SMG & $\mathrm{FO}$ & 382.4 & 1567.9 \\
\hline 1377 & Road & $1377-0-2$ & SP & SMG & $\mathrm{FO}$ & 348.8 & 1429.9 \\
\hline 858 & Road & $858-0-2$ & SP & SMG & $\mathrm{FO}$ & 198.0 & 811.6 \\
\hline $858-1$ & Road & $858-1-2$ & SP & SMG & $\mathrm{FO}$ & 205.7 & 843.3 \\
\hline $858-4$ & Road & $858-4-2$ & $\mathrm{SP}$ & SMG & $\mathrm{FO}$ & 2544.9 & 10434.2 \\
\hline
\end{tabular}

In this paper, a 3D surface and 3D underground cadastral map is proposed. In order to create the 3D surface, a 1:1000 digital map containing $\pm 0.3 \mathrm{~m}$ of vertical error is used [82]. Then, this map is integrated with 2D surface parcel boundaries to produce height information on the $3 \mathrm{D}$ underground cadastral property. It is possible to represent the relative height, which is the vertical distance between the 3D surface and 3D underground cadastral property. The relative height is determined by calculating the distance between all corner points on the ceiling of 3D underground construction parcel and 3D underground legal parcel, and their corresponding points of 3D surface. This relative height information is critical to the verification of the range of underground ownership with respect to the surface height. It can establish rights, responsibilities, and restrictions related to the underground property by preventing the conflict of ownership right, protecting the developed underground facility, and facilitating public use. Figure 12 illustrates a 3D surface and 3D underground cadastral map: (a) is the top view of the 3D underground cadastral map by the transparency effect; (b) is the front view of the 3D underground property (see the red arrow in Figure 12a); and (c) is the side view of the 3D underground property (see the blue arrow in Figure 12a).

The three types of 3D underground cadastral maps can clearly represent the status of 3D underground property, and so, by provision of sufficient geometric information, can support registration of legal information including rights, responsibilities, and restrictions. 




(b)

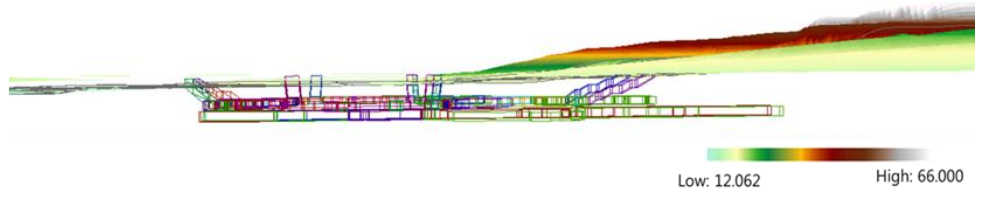

(c)

Figure 12. 3D surface and 3D underground cadastral map (unit: meters): (a) top view of 3D underground parcel with transparency effect; (b) Front view of 3D underground property (direction of red arrow on Figure 12a); and (c) Side view of 3D underground property (direction of blue arrow on Figure 12a).

\section{Conclusions}

The proposed method represents a new concept in the registration of underground property in relation to a 3D underground cadastral system. Specifically, the method represents accurate and diverse spatial information on 3D underground property for legitimization of registration of rights, responsibilities, and restrictions, as well as for prevention or adjudication of vertical land disputes, proper land compensation, and improvement of the taxation system. The major contribution of this study is its implementation, for the first time, of a 3D underground cadastral system in a real-world setting: the Gangnam subway station in Seoul, Korea.

In order to fulfill its intended function, the 3D underground cadastral system requires effective and efficient indoor mapping technology; therefore, the authors chose a terrestrial laser scanner for relevant indoor mapping, which utility has been extensively employed in the as-built BIM arena. The proposed method consists of four processing steps: (1) geometric modeling of underground construction components; (2) as-built BIM in Revit software; (3) accuracy assessment of as-built BIM; (4) production of 3D underground cadastral maps based on as-built BIM: an isometric view of the 
3D underground cadastral map, a 2D surface parcel with footprints of the 3D underground cadastral map and the 3D surface and 3D underground cadastral maps. In the present study, the proposed method was, as noted above, applied to a real-world underground infrastructure, Gangnam subway station in Seoul, Korea. The 3D underground cadastral maps based on indoor mapping for as-built BIM can, by clearly identifying the underground physical situation, facilitate better decision-making in the management, maintenance, and development of underground property. While working on the implementation, we could confirm the effectiveness and efficiency of the proposed indoor mapping method for as-built BIM and, eventually, 3D underground cadastral mapping. Simple polylines, which are the boundaries of the underground property, were extracted from the huge-size raw point cloud data, which BIM software might not be able to handle or even to import. We could also prove that geometric modeling can be a powerful solution to the problem of producing accurate 3D underground cadastral mapping in an efficient manner.

In order to apply the method to the 3D underground cadastral system, accuracy assessment was conducted based on target points acquired by total station. The result showed that the Euclidean average distance error was $0.086 \mathrm{~m}$ and the RMSE $0.095 \mathrm{~m}$. This error tolerance, based on the Euclidean average distance error and according to the Korea cadastral surveying accuracy standard, was acceptable within $10 \mathrm{~cm}$ for a 2D digital cadastral map. Overall, the proposed indoor mapping for as-built BIM was proven to be an effective solution satisfying the requirements of the $3 \mathrm{D}$ underground cadastral system.

The authors recognize that the proposed new framework for 3D underground cadastral system will require additional modification for real-world applications. Specifically, several issues have to be resolved, not only on the technical side but also on the administration and law side, such as the definition of "3D underground cadastre", including the numbering system of underground parcel ID's, underground land categories, area and volume, and the reestablishment of "the scope of justifiable profit" in the Civil Law to guarantee underground ownership. Finally, in order to improve the usability and potential value of the 3D underground cadastral system, semantic information on 3D underground properties has to be provided in proven legitimate and efficient ways. In this regard, International Property Measurement Standards [83], which represent an important international initiative to ensure that measurement of various types of properties is performed in a consistent way, need to be adopted to ensure efficient and effective land management service.

Acknowledgments: The terrestrial laser scanning data were provided by the Korea Ministry of Land, Infrastructure, and Transport (MOLIT).This research, "Geospatial Big Data Management, Analysis and Service Platform Technology Development" was supported by a grant (15NSIP-B081011-02) from the MOLIT, under the national spatial information research program supervised by the KAIA (Korea Agency for Infrastructure Technology Advancement).

Author Contributions: Sangmin Kim contributed to the generation of the primary idea and wrote the paper. Sangmin Kim and Jeonghyun Kim performed accuracy assessment and field surveying. Jaehoon Jung designed the experiments and provided comments. Corresponding author Joon Heo proposed the research idea and provided guidance throughout the course of the research.

Conflicts of Interest: The authors declare no conflict of interest.

\section{References}

1. FIG, F. Statement on the cadastre. Int. Fed. Surv. 1995, 2, 22-27.

2. Stoter, J.; Ploeger, H.; van Oosterom, P. 3D cadastre in the netherlands: Developments and international applicability. Comput. Environ. Urb. Syst. 2013, 40, 56-67. [CrossRef]

3. Pouliot, J.; Vasseur, M.; Boubehrezh, A. How the ISO 19152 land administration domain model performs in the comparison of cadastral systems: A case study of condominium/co-ownership in quebec (Canada) and alsace moselle (France). Comput. Environ. Urb. Syst. 2013, 40, 68-78. [CrossRef]

4. Paasch, J.; Paulsson, J. Terminological aspects on three-dimensional real property. Nord. J. Surv. Real Estate Res. 2012, 8, 81-97. 
5. Van Oosterom, P.; Stoter, J.; Ploeger, H.; Thompson, R.; Karki, S. World-Wide Inventory of the Status of 3D Cadastres in 2010 and Expectations for 2014. In Proceedings of the FIG Working Week 2011 Bridging the Gap between Cultures \& 6th National Congress of ONIGT, Marrakech, Morocco, 18-22 May 2011; pp. 1-21.

6. SIRI. A Study on 3D Cadastre for International Standardization; Spatial Information Research Institute: Seoul, Korea, 2014; pp. 1-123.

7. MLTMA. A Study on the Compensation of Above and Below Land; Ministry of Land Transport and Maritime Affairs: Gyeonggi-do, Korea, 2012; pp. 1-237.

8. Ji-Sun, S.; Keun-Chul, A.; Myeong-Hun, L. A study on the issue of legal right in utilizing underground space—focusing on the problem of the use of land and compensation. J. Korea Plan. Assoc. 2012, 47, 101-111.

9. Jeon, B.J.; Lee, C.Y.; Park, Y.G.; Kim, K.H. A plan for registration underground space for 3D cadastre. J. Korea Plan. Assoc. 2012, 14, 79-94.

10. Kim, Y.; Lee, S. A study on improving cadastre system and cadastre-related laws for introducing 3D cadastre. Korea Spat. Plan. Rev. 2006, 9, 147-162.

11. Patraucean, V.; Armeni, I.; Nahangi, M.; Yeung, J.; Brilakis, I.; Haas, C. State of research in automatic as-built modelling. Adv. Eng. Inform. 2015, 29, 162-171. [CrossRef]

12. Volk, R.; Stengel, J.; Schultmann, F. Building information modeling (BIM) for existing buildings—Literature review and future needs. Autom. Constr. 2014, 38, 109-127. [CrossRef]

13. Bhatla, A.; Choe, S.Y.; Fierro, O.; Leite, F. Evaluation of accuracy of as-built 3D modeling from photos taken by handheld digital cameras. Autom. Constr. 2012, 28, 116-127. [CrossRef]

14. Jung, J.; Hong, S.; Jeong, S.; Kim, S.; Cho, H.; Hong, S.; Heo, J. Productive modeling for development of as-built bim of existing indoor structures. Autom. Constr. 2014, 42, 68-77. [CrossRef]

15. Heo, J.; Jeong, S.; Park, H.-K.; Jung, J.; Han, S.; Hong, S.; Sohn, H.-G. Productive high-complexity 3D city modeling with point clouds collected from terrestrial lidar. Comput. Environ. Urb. Syst. 2013, 41, $26-38$. [CrossRef]

16. Stoter, J.E.; van Oosterom, P. 3D Cadastre in an International Context: Legal, Organizational, and Technological Aspects; Crc Press: Boca Raton, FL, USA, 2006.

17. Aien, A.; Kalantari, M.; Rajabifard, A.; Williamson, I.; Wallace, J. Towards integration of 3D legal and physical objects in cadastral data models. Land Use Policy 2013, 35, 140-154. [CrossRef]

18. Jazayeri, I.; Rajabifard, A.; Kalantari, M. A geometric and semantic evaluation of 3D data sourcing methods for land and property information. Land Use Policy 2014, 36, 219-230. [CrossRef]

19. Overby, J.; Bodum, L.; Kjems, E.; Iisoe, P. Automatic 3D building reconstruction from airborne laser scanning and cadastral data using hough transform. Int. Arch. Photogramm. Remote Sens. Spat. Inform. Sci. 2004, 34, 296-301.

20. Majdik, A.L.; Verda, D.; Albers-Schoenberg, Y.; Scaramuzza, D. Micro Air Vehicle Localization and Position Tracking from Textured 3D Cadastral Models. In Proceedings of the Robotics and Automation (ICRA), 2014 IEEE International Conference, Hong Kong, China, 31 May-7 June 2014; pp. 920-927.

21. Suveg, I.; Vosselman, G. 3D reconstruction of building models. Int. Arch. Photogramm. Remote Sens. Spat. Inform. Sci. 2000, 33, 538-545.

22. Xiong, X.; Adan, A.; Akinci, B.; Huber, D. Automatic creation of semantically rich $3 \mathrm{D}$ building models from laser scanner data. Autom. Constr. 2013, 31, 325-337. [CrossRef]

23. Liang, X.; Litkey, P.; Hyyppä, J.; Kaartinen, H.; Vastaranta, M.; Holopainen, M. Automatic stem mapping using single-scan terrestrial laser scanning. IEEE Trans. Geosci. Remote Sens. 2012, 50, 661-670. [CrossRef]

24. Pfeifer, N.; Briese, C. Geometrical aspects of airborne laser scanning and terrestrial laser scanning. Int. Arch. Photogramm. Remote Sens. Spat. Inform. Sci. 2007, 36, 311-319.

25. Arayici, Y. An approach for real world data modelling with the $3 \mathrm{D}$ terrestrial laser scanner for built environment. Autom. Constr. 2007, 16, 816-829. [CrossRef]

26. Alba, M.I.; Barazzetti, L.; Scaioni, M.; Rosina, E.; Previtali, M. Mapping infrared data on terrestrial laser scanning 3D models of buildings. Remote Sens. 2011, 3, 1847-1870. [CrossRef]

27. Hong, S.; Jung, J.; Kim, S.; Cho, H.; Lee, J.; Heo, J. Semi-automated approach to indoor mapping for 3D as-built building information modeling. Comput. Environ. Urb. Syst. 2015, 51, 34-46. [CrossRef]

28. Haala, N.; Anders, K.-H. In acquisition of 3D urban models by analysis of aerial images, digital surface models, and existing 2D building information. Int. Soc. Opt. Photonics 1997, 3072, 212-222. 
29. Taneja, A.; Ballan, L.; Pollefeys, M. Registration of spherical panoramic images with cadastral 3D models. In Proceedings of the IEEE 2012 Second International Conference on 3D Imaging, Modeling, Processing, Visualization and Transmission (3DIMPVT), Yichang, China, 21-23 April 2012; pp. 479-486.

30. Taneja, A.; Ballan, L.; Pollefeys, M. City-scale change detection in cadastral 3D models using images. In Proceedings of the 2013 IEEE Conference on Computer Vision and Pattern Recognition (CVPR), Portland, OR, USA, 23-28 June 2013; pp. 113-120.

31. Hammoudi, K.; Dornaika, F. A featureless approach to 3D polyhedral building modeling from aerial images. Sensors 2010, 11, 228-259. [CrossRef] [PubMed]

32. Baillard, C.; Zisserman, A. A plane-sweep strategy for the $3 \mathrm{D}$ reconstruction of buildings from multiple images. Int. Arch. Photogramm. Remote Sens. 2000, 33, 56-62.

33. Baillard, C.; Schmid, C.; Zisserman, A.; Fitzgibbon, A. Automatic line matching and 3D reconstruction of buildings from multiple views. In Proceedings of the ISPRS Conference on Automatic Extraction of GIS Objects from Digital Imagery, Munich, Germany, 8-10 September 1999; pp. 69-80.

34. Sahin, C.; Alkis, A.; Ergun, B.; Kulur, S.; Batuk, F.; Kilic, A. Producing 3D city model with the combined photogrammetric and laser scanner data in the example of taksim cumhuriyet square. Opt. Lasers Eng. 2012, 50, 1844-1853. [CrossRef]

35. Chen, L.-C.; Teo, T.-A.; Hsieh, C.-H.; Rau, J.-Y. Reconstruction of building models with curvilinear boundaries from laser scanner and aerial imagery. In Advances in Image and Video Technology; Springer: Berlin, Germany, 2006; pp. 24-33.

36. Hongjian, Y.; Shiqiang, Z. 3D building reconstruction from aerial CCD image and sparse laser sample data. Opt. Lasers Eng. 2006, 44, 555-566. [CrossRef]

37. Matikainen, L.; Kaartinen, H.; Hyyppä, J. Classification tree based building detection from laser scanner and aerial image data. Int. Arch. Photogramm. Remote Sens. Spat. Inform. Sci. 2007, 36, 280-287.

38. Cheng, L.; Gong, J.; Li, M.; Liu, Y. 3D building model reconstruction from multi-view aerial imagery and lidar data. Photogramm. Eng. Remote Sens. 2011, 77, 125-139. [CrossRef]

39. Hammoudi, K.; Dornaika, F.; Soheilian, B.; Paparoditis, N. Extracting wire-frame models of street facades from 3D point clouds and the corresponding cadastral map. Remote Sens. Spat. Inform. Sci. 2010, 38, 91-96.

40. $\mathrm{Pu}, \mathrm{S}$.; Vosselman, G. Building facade reconstruction by fusing terrestrial laser points and images. Sensors 2009, 9, 4525-4542. [PubMed]

41. Krauß, T.; Lehner, M.; Reinartz, P. Generation of coarse 3D models of urban areas from high resolution stereo satellite images. In Proceedings of the ISPRS Congress 2008, Beijing, China, 3-11 June 2008; pp. 1091-1098.

42. Eastman, C.; Eastman, C.M.; Teicholz, P.; Sacks, R. Bim Handbook: A Guide to Building Information Modeling for Owners, Managers, Designers, Engineers and Contractors; John Wiley \& SonsHobke: Hoboken, NJ, USA, 2011.

43. Anil, E.B.; Tang, P.; Akinci, B.; Huber, D. Assessment of the Quality of As-Is Building Information Models Generated From Point Clouds Using Deviation Analysis; International Society for Optics and Photonics: Bellingham, WA, USA, 2011; pp. 78613-78640.

44. GSA, U. Gsa Bim Guide for 3D Imaging; US General Services Administration: Washington, DC, USA, 2009.

45. Klein, L.; Li, N.; Becerik-Gerber, B. Imaged-based verification of as-built documentation of operational buildings. Autom. Constr. 2012, 21, 161-171. [CrossRef]

46. El-Hakim, S.F.; Gruen, A. Videometrics and Optical Methods For 3D Shape Measurement; SPIE: Bellingham, WA, USA, 2001.

47. Jaselskis, E.J.; Gao, Z.; Walters, R.C. Improving transportation projects using laser scanning. J. Constr. Eng. Manag. 2005, 131, 377-384. [CrossRef]

48. Tang, P.; Akinci, B.; Huber, D. Quantification of edge loss of laser scanned data at spatial discontinuities. Autom. Constr. 2009, 18, 1070-1083. [CrossRef]

49. Tang, P.; Huber, D.; Akinci, B.; Lipman, R.; Lytle, A. Automatic reconstruction of as-built building information models from laser-scanned point clouds: A review of related techniques. Autom. Constr. 2010, 19, 829-843. [CrossRef]

50. Golparvar-Fard, M.; Bohn, J.; Teizer, J.; Savarese, S.; Peña-Mora, F. Evaluation of image-based modeling and laser scanning accuracy for emerging automated performance monitoring techniques. Autom. Constr. 2011, 20, 1143-1155. [CrossRef] 
51. Remondino, F.; Guarnieri, A.; Vettore, A. 3D modeling of Close-Range Objects: Photogrammetry or Laser Scanning. Int. Soc. Opt. Photonics 2005, 5665, 216-225.

52. Martínez, J.; Soria-Medina, A.; Arias, P.; Buffara-Antunes, A.F. Automatic processing of terrestrial laser scanning data of building facades. Autom. Constr. 2012, 22, 298-305. [CrossRef]

53. Boulaassal, H.; Landes, T.; Grussenmeyer, P.; Tarsha-Kurdi, F. Automatic Segmentation of Building Facades Using Terrestrial Laser Data; ISPRS: Espoo, Finland, 2007; pp. 65-70.

54. Fischler, M.A.; Bolles, R.C. Random sample consensus: A paradigm for model fitting with applications to image analysis and automated cartography. Commun. ACM 1981, 24, 381-395. [CrossRef]

55. Vosselman, G.; Dijkman, S. 3D building model reconstruction from point clouds and ground plans. Int. Arch. Photogramm. Remote Sens. Spat. Inform. Sci. 2001, 34, 37-44.

56. Liu, Y.; Xiong, Y. Automatic segmentation of unorganized noisy point clouds based on the gaussian map. Comput. Aided Des. 2008, 40, 576-594. [CrossRef]

57. Thrun, S.; Martin, C.; Liu, Y.; Hähnel, D.; Emery-Montemerlo, R.; Chakrabarti, D.; Burgard, W. A real-time expectation-maximization algorithm for acquiring multiplanar maps of indoor environments with mobile robots. IEEE Trans. Robot. Autom. 2004, 20, 433-443. [CrossRef]

58. Schuster, H.-F. Segmentation of lidar data using the tensor voting framework. Int. Arch. Photogramm. Remote Sens. Spat. Inform. Sci. 2004, 35, 1073-1078.

59. Rabbani, T.; van den Heuvel, F.; Vosselmann, G. Segmentation of point clouds using smoothness constraint. Int. Arch. Photogramm. Remote Sens. Spat. Inform. Sci. 2006, 36, 248-253.

60. Rusu, R.B.; Cousins, S. 3D is here: Point cloud library (PCL). In Proceedings of the 2011 IEEE International Conference on Robotics and Automation (ICRA), Shanghai, China, 9-13 May 2011; pp. 1-4.

61. Schnabel, R.; Wahl, R.; Klein, R. Efficient Ransac for Point-Cloud Shape Detection, Computer Graphics Forum; Wiley Online Library: Hoboken, NJ, USA, 2007; pp. 214-226.

62. Douillard, B.; Underwood, J.; Kuntz, N.; Vlaskine, V.; Quadros, A.; Morton, P.; Frenkel, A. On the segmentation of 3D lidar point clouds. In Proceedings of the 2011 IEEE International Conference on Robotics and Automation (ICRA), Shanghai, China, 9-13 May 2011; pp. 2798-2805.

63. Motameni, H.; Norouzi, M.; Jahandar, M.; Hatami, A. Labeling Method in Steganography. Proc. World Acad. Sci. Eng. Technol. 2007, 24, 349-354.

64. Autodesk Revit 2014. Available online: http://www.autodesk.com (accessed on 10 May 2015).

65. Falzon, K.; Williamson, I. Digital lodgement of cadastral survey data in australia-issues and options. Aust. Surv. 2001, 46, 62-71.

66. Guo, R.; Li, L.; Ying, S.; Luo, P.; He, B.; Jiang, R. Developing a 3D cadastre for the administration of urban land use: A case study of shenzhen, china. Comput. Environ. Urb. Syst. 2013, 40, 46-55. [CrossRef]

67. Shojaei, D.; Kalantari, M.; Bishop, I.D.; Rajabifard, A.; Aien, A. Visualization requirements for 3D cadastral systems. Comput. Environ. Urb. Syst. 2013, 41, 39-54. [CrossRef]

68. Karki, S.; Thompson, R.; McDougall, K. Development of validation rules to support digital lodgement of 3D cadastral plans. Comput. Environ. Urb. Syst. 2013, 40, 34-45. [CrossRef]

69. Van Oosterom, P.; Stoter, J.; Ploeger, H.; Lemmen, C.; Thompson, R.; Karki, S. Initial analysis of the second FIG 3D cadastres questionnaire: Status in 2014 and expectations for 2018. In Proceedings of the 4th International FIG 3D Cadastre Workshop, Dubai, United Arab Emirates, 9-11 November 2014.

70. Jazayeri, I. Trends in 3D land information collection and management. A Natl. Infrastruct. Manag. Land Inform. 2012, 3, 81-87.

71. Ying, S.; Guo, R.; Li, L.; He, B. Application of 3D Gis to 3D Cadastre in Urban Environment; Developments and Practices: Shenzhen, China, 2012; pp. 25-26.

72. Elberink, S.O.; Vosselman, G. 3D modelling of topographic objects by fusing 2D maps and lidar data. In Proceedings of the ISPRS TC-IV Intl Symp on Geospatial Databases for Sustainable Development, Goa, India, 17-30 September 2006; pp. 199-204.

73. Flamanc, D.; Maillet, G.; Jibrini, H. 3D city models: An operational approach using aerial images and cadastral maps. Int. Arch. Photogramm. Remote Sens. Spat. Inform. Sci. 2003, 34, 53-58.

74. Stoter, J.E.; Van Oosterom, P. Technological aspects of a full 3D cadastral registration. Int. Arch. Photogramm. Remote Sens. Spat. Inform. Sci. 2005, 19, 669-696. [CrossRef] 
75. Vandysheva, N.; Ivanov, A.; Pakhomov, S.; Spiering, B.; Stoter, J.; Zlatanova, S.; Van Oosterom, P. Design of the $3 \mathrm{D}$ cadastre model and development of the prototype in the russian federation. In Proceedings of the 2nd International Workshop on 3D Cadastres, Delft, The Netherlands, 16-18 November 2011.

76. Urban Planning Information System. Available online: http:/ /www.upis.go.kr (accessed on 11 July 2015).

77. Land Use Regulations Information System. Available online: http://luris.mltm.go.kr (accessed on 11 July 2015).

78. Seoul Metro. Records of transportation in 2014, 2015. Available online: http://www.seoulmetro.co.kr/ (accessed on 25 May 2015).

79. Reit, B. The 7-parameter transformation to a horizontal geodetic datum. Surv. Rev. 1998, 34, 400-404. [CrossRef]

80. Hong Sung, E. Comparing efficiency of numerical cadastral surveying using total station and RTK-GPS. J. Korean Soc. Geo. Spat. Inform. Syst. 2007, 15, 87-96.

81. Greenwalt, C.R.; Shultz, M.E. Principles of Error Theory and Cartographic Applications; DTIC Document: Fort Belvoir, VA, USA, 1962.

82. Lee, H. Revision of 1/1000 digital map for application of 3 Dimensional Geospatial Data. J. Korean Soc. Surv. Geo. Photogramm. Cartogr. 2014, 32, 77-86. [CrossRef]

83. IPMS. International Property Measurement Standards: Office Buildings; International Property Measurement Standards Coalition (IPMSC): London, UK, 2014.

(C) 2015 by the authors; licensee MDPI, Basel, Switzerland. This article is an open access article distributed under the terms and conditions of the Creative Commons by Attribution (CC-BY) license (http:/ / creativecommons.org/licenses/by/4.0/). 